\title{
An Exploration of Inclusive Education Policies Aimed at Students with Disabilities vs. the Panorama of EFL Scenarios in Colombia. ${ }^{1}$
}

\author{
Una Exploración de Políticas de Educación Inclusiva \\ dirigidas a estudiantes con Discapacidades en el panorama \\ vs. el panorama de enseñanza de inglés como lengua \\ extranjera en escenarios colombianos
}

\author{
Dayra Piedad Ochoa Alpala² \\ Institución Educativa Rafael Reyes. \\ dayrapiedad8a@hotmail.com
}

Received: March 7, 2016

Accepted: June 14, 2016

How to cite this article (APA, $6^{\text {th }}$ ed.): Ochoa, D. (2016). An Exploration of Inclusive Education Policies Aimed at Students with Disabilities vs. the Panorama of EFL Scenarios in Colombia. Enletawa Journal, 9 (2), 79-92.

\begin{abstract}
This article reflects upon the policies that regulate inclusive education in Colombia for students with disabilities and contrasts it with the reality of EFL teaching/learning nowadays. The concept of inclusion has gained interest among government officials and scholars in recent decades; as a result, much inclusivity legislation has been created to guarantee access for disabled students in mainstream

1 The article is a reflective paper that arose from an experience in a sociolinguistics class that is one of the seminars that the Master's in Language Teaching offers.

2 Holds a B.A in Modern Languages from Universidad Pedagógica y Tecnológica de Colombia and is a student of third semester in the Master's program in Language Teaching. She currently teaches English as a foreign language at Juan de Castellanos University. She has worked as an English and Spanish teacher in different institutions from Boyacá. Her research interests include virtual tools and co-regulation in EFL learning.
\end{abstract}


schools. However, there are not clear procedures and adequate scenarios to address foreign language education in Colombia for this population, resulting in more exclusion, discrimination and lack of opportunities for disabled learners.

Key Words: Students with disabilities, Inclusion, Policies, EFL Teachinglearning, Discrimination.

\section{Resumen}

Este artículo presenta una reflexión acerca de las políticas que regulan la educación inclusiva en Colombia para estudiantes con discapacidades, en contraste con la realidad de la enseñanza y aprendizaje del inglés como lengua extranjera hoy en día. El concepto de inclusión ha ganado interés entre el gobierno y los eruditos en las últimas décadas, de manera que, se han creado muchas legislaciones inclusivas para garantizar el acceso a los estudiantes con discapacidad en las escuelas ordinarias. Sin embargo, no hay procedimientos claros y escenarios adecuados para abordar la enseñanza de idiomas extranjeros en esta población en Colombia, promoviendo más la exclusión, la discriminación y la falta de oportunidades.

Palabras clave: Estudiantes con discapacidades, Inclusión, Políticas, Enseñanza y Aprendizaje del inglés como lengua extranjera, Discriminación. 


\section{Introduction}

A disability entails a physical or mental impairment that substantially limits one or more fundamental life activities of an individual such as walking, seeing and hearing (Americans with disabilities act of 1990). According to statistics from DANE (Departamento Administrativo Na-cional de Estadística), there are 2,624,898 disabled people in Colombia, which represents $6.3 \%$ of the whole population. It is estimated that about the $22.5 \%$ of these people are illiterate, while $9.1 \%$ have motor disabilities, $14 \%$ have sensory disabilities, $34.8 \%$ have cognitive disabilities, and $19.8 \%$ have mental disabilities.

Based on the latest statistics and the need to provide this segment of the population with opportunities to acquire values, knowledge, behaviors, and new ways to participate in society, the Colombian educational system has developed a new concept of inclusion aiming to ensure equal rights and participation for people with impairments. According to Law 1098 (Colombian Infancy and Adolescence Code Act 36, 2006), it is a fundamental right for children with any kind of disability to have the benefit of a highquality life and to be provided with any required assistance to foster their development in order to reduce their vulnerability and allow them to take an active part in society. To that end, disabled people have been immersed in mainstream learning settings and regular classrooms.

Private and public institutions are obliged to enroll students with different kinds of impairments. It has been assumed that teachers should bear the responsibility for the implementation of inclusive practices, without considering that these practices also depend on some other aspects such as funding, timetabling, availability of time for lesson planning and designing materials, access to specialized support, class size, as well as the severity of the disability itself (Eisenman, Pleet, Wandry, and McGinley, 2011). This can lead to a teachers' feeling of stress and a lack of confidence to handle the diverse special needs that can be encountered in classrooms nowadays.

Likewise, there is also an underlying belief that a good inclusive practice is somehow consistently quantifiable and can measured in the same way in all educational institutions, regardless of its context-dependent nature. This is why some schools reject the official and institutional policies as being only oneway paths, where disabled students are expected to learn via methodology and resources that do not correspond to their individual characteristics and the realities they find themselves in. Thus, being inclusive is not only a matter of providing a physical context for people with impairments but also entails rethinking various preconceptions, behaviors and attitudes to ensure that these learners can truly develop within conventional environments. 
Regarding the particular case of foreign language learning in Colombia, the MEN (Ministry of National Education) aims to reach high levels of English proficiency among high school graduates and higher institution students by 2019 without excluding any community; consequently, it has initiated the bilingual program "Colombia, very well" based upon the Basic Standards of Competence in Foreign Languages from the Common European Framework, in an effort to guarantee access to bilingual education for all Colombian students across education levels. However, there are no policies yet to address bilingual education among the wider population with disabilities, which are now part of the regular classrooms in many institutions of Colombia.

Based on the previously stated concerns, this article will discuss the laws that regulate inclusive education in Colombia and will contrast them with the current bilingual policies and the array of challenges that schools and EFL teachers face in trying to promote bilingual practices within this population and involving students with impairments in regular learning contexts.

\section{Theoretical Review}

\section{Inclusive Education.}

The notion of inclusion has its roots in special needs education of the $19^{\text {th }}$ century. Its pioneers argued for and helped to develop provisions for children and young people who were excluded from education (Reynolds and Ainscow, 1994). Later on, in the $20^{\text {th }}$ century, governments concerned themselves with the creation of special education schools since it was considered that children with disabilities could not benefit from ordinary schooling. This model remained in place for many years, but as reflection on inclusive education increased, it was questioned whether segregating children with disabilities was really the appropriate response to meet their needs.

Concerns about equal access and integration became the core of social and political reforms, and the new vision of education for special needs population emerged into legislative changes that ensured opportunities for the last stigmatized disabled groups within regular settings. In those settings, disabled learners had to be afforded the same rights as the other students, and they were taught in accordance with their individual characteristics in mutual collaboration with various societal stakeholders. Thus, their inclusion and sustained participation in the mainstream educational system must be guaranteed. Putnam (1998) believed that students should not be removed routinely from mainstream classrooms to receive special assistance because doing so highlights their disabilities, disrupts their education, and thus essentially violates their rights.

In this regard, participants from 92 governments and 25 international organizations took part in the Con- 
ference of Salamanca that was held in 1994. They came together to consider the changes needed in order to promote new policies for inclusive education serving all kinds of students, particularly disabled ones. Although the main focus of this conference was special needs education, they reached the idea that: "regular schools with inclusive orientation are the most effective means of combating discriminatory attitudes, creating welcoming communities, building an inclusive society and achieving education for all; moreover, they provide an effective education to the majority of children and improve the efficiency and ultimately the cost-effectiveness of the entire education system" (UNESCO, 1994). Based on this new perspective of inclusion, countries had to design their own educational policies to integrate different kinds of students, including those with disabilities, into the mainstream schools.

In Colombia, different legislative acts have been created to address inclusion and to regulate the changes that institutions must embrace to enroll students with disabilities and exceptional talents in primary, secondary and higher education. In the General Law of Education 115, the Ministry of National Education (MEN, 1994) claimed that "Educational institutions, directly or through agreements, will organize educational and therapeutic actions that allow the process of academic and social integration of these students." MEN also established some guidelines for inclusive education based on six main philosophies: Participation (to take an active part in the institution), Diversity (an inherent feature of individuals), Interculturality (the consideration of and interaction with other cultures), Equity (to have equal ease of access), Quality (suitable learning conditions), and $A p$ propriateness (fitting for a particular purpose, person, occasion, etc.).

Likewise, the legislative Act 2082 (1996) proposes to carry out "curricular, organizational, educational, physical and technological adjustments as well as resources and teacher training." It includes four principles that must guide educational practices for people with disabilities or exceptional talents: Social and educational integration (special pedagogical and therapeutic support which is regulated and organized in the Act 366, 2009), human development (suitable conditions to develop skills, address individual interests, and acquire cultural, ethical and intellectual values), opportunity and balance (facilitating access, sustained participation, and adequate coverage of people with disabilities and exceptional talents), and specific support (specific, individualized and qualified attention according to the disability or exceptionality).

\section{Challenges for Inclusive Education in EFL Scenarios in Colombia.}

Despite the creation and implementation of policies, the current situation of inclusive education of 
Colombia faces a lot of misconceptions and challenges, in practice. Not all of the educational institutions are ready to ensure best practices for disabled students either because of the lack of resources and training or due to the maintenance of a fossilized perspective that sees continued segregation of students with different characteristics. Oliver (1990) declares:

All disabled people experience disability as social restriction, no matter whether these restrictions occur as a consequence of inaccessible built environments, questionable notions of intelligence and social competence, the inability of the general public to use sign language, the lack of reading material in Braille or hostile public attitudes to people with non-visible disabilities ( $p$. 55).

Teaching disabled students requires special environments. According to Londoño (2012), they need

Entertaining activities that stimulate attention and memory, optimizing the development of the body and the senses due to the fact that individuals coordinate their body movements. Games were found to be highly positive when teaching cognitively impaired people since they increase the partaking level in class activities, (p. 102).

Most times, however, neither physical spaces nor pedagogical approaches in regular education contexts promote these practices to address disabled students within the classroom. That is why "mainstream schools will require support to ensure that pupils have appropriate access to the statutory curriculum and that they make suitable progress," (DENI, 2006, p. 10).

Lack of special environments and appropriate conditions for inclusive education has constituted one of the major challenges that English teachers have had to deal with in the last decades. Although it is mandatory to teach different kind of needs in regular classrooms, teachers seldom have the resources or knowledge to engage disabled students in the class procedures and to achieve results in their English learning process. As a result, they often remain in the first phase of school's development in terms of inclusion proposed by Ainscow (1999):

The first phase is to be present, make children enter school; however, they may be present but ignored [...] The following [second phase] occurs when children are not only present, but participate, contribute, are welcome, and their voice is listened to [...] The third, and [this] is the ultimate goal, is when besides being present and participating, they learn useful things for themselves ( $p .87$ ).

To get into the final step of inclusion, schools need more than a series of policies that sometimes are not linked to what teachers really face in the classroom. Thus, the absence of clear guidelines and studies on this arena remains problematic.

Londoño (2012) argues that research on the language learning of people with 
cognitive disabilities (CD) has focused on investigating the strengths and weaknesses of this population in terms of first and second language acquisition. However, in terms of foreign language teaching, there is still a lack of information which might serve as an underpinning for language teachers' successful practices when faced with disabled learners in regular-education classrooms. Foreign language teachers need to start doing research on this field to enrich not only their own practices but also those in other contexts also challenged by accommodating students with different kinds of impairments.

English language education for students with disabilities is neither supported by the National Bilingual Program known (NBP) as "Colombia, very well," created to foster English language teaching in all Colombian students for the next ten years, nor by the standards and competences that govern what a learner is supposed to perform with the language at each level of instruction. Both documents propose practices and resources for only some kinds of populations and institutions and do not include what a disabled student should achieve and how, despite that their goal is to raise bilingualism among all Colombian students, disabled ones are being excluded.

Usma (2009) states that "like any other educational reforms, the bilingualism program brings opportunities for some groups and individuals but mostly generates processes of inequality, exclusion and social stratification with the new discourses and practices that are adopted" (p. 23). For him, the instrumentalist notion of Spanish-English bilingualism not only excludes indigenous languages and other foreign languages, but also imposes discourse and practices imported to the country to the detriment of local knowledge.

\section{Factors in Upholding Inclusion in Regular Institutions.}

The Department of Education and Science (2007) came up with a range of factors that can help institutions and teachers to enhance effective teaching of students in an inclusive setting and strengthen policy development. These guidelines will be compared in the following pages to the reality of educational settings nowadays, particularly the foreign language learning ones:

A variety of teaching strategies and approaches/ The content of lessons is matched to the needs of the students and to their levels of ability: In foreign language classrooms, teachers are trained to use a wide range of strategies according to students needs and interests. They regularly look for methods to enhance students' learning process and often update themselves on new trends in teaching. They even enroll postgraduate programs and professional development courses to strengthen their teaching pedagogies, 
but there are usually not many options to prepare them for teaching students with disabilities, which is why teachers often lack the knowledge to include strategies to serve disabled people in their teaching agenda. Cardona (2006) claims that most of the young learners diagnosed as cognitively impaired are brought into the regular education system, yet teachers do not always develop their practices according to the learners' characteristics and needs.

In addition, there is not enough existing literature that orients EFL teachers towards this matter. It is assumed that they must propose and implement concrete actions to address any disability that comes into the classroom, but without specific orientations on how to do so, teaching a foreign language to a disabled student will remain a challenging endeavor with often discouraging outcomes. According to UNESCO (2009), " an inclusive school must offer possibilities and opportunities for a range of working methods and individual treatment to ensure that no child is excluded from companionship and participation in the school." (p.17) These opportunities for variety and individual treatment are limited because of lack of suitable conditions and preparation. Moreover, individual treatment is difficult when teachers face large sized groups with very few resources.

On the other hand, the National Bilingual Program" Colombia, very well" aims to raise English teachers' competences and their teaching skills, yet without any reference to training on special needs, these kinds of populations are being excluded in the objectives and practices of the NBP. Hurtado and Agudelo (2014) claim that "inclusion cannot be carried out by the teacher, taking into account its current preparation" (p. 102). This might suggest that in an attempt to be inclusive, legislation might paradoxically promote greater exclusion by mandating something for which there is no preparation and therefore may not materialize. Teacher pre-service and in-service programs should include inclusive education approaches to strengthen pedagogical tools that serve diversity in curricular and classroom matters.

Clear learning objectives are outlined at the beginning of the lesson, reference is made to them during the lesson, and a review with the students of what has been learned occurs at the end of the lesson: Every teacher states the aims to be achieved during the development of the class, and they have to be communicated to students in order for them to have a clear concept of what they are expected to do, how, and with what.

In terms of the English course syllabus, the goals set for the classes cover the majority of students' characteristics. It is not customary to adapt those goals for disabled students; thus they are expected to reach the 
same objectives in the same ways as regular students do.

Formative assessment strategies for identifying the students' progress that are used to help inform teaching approaches: Bilingual education nowadays is measured by the results it gets, and students are categorized in different levels of proficiency (A1, A2, B1, B2, C1, C2) according to the Common European Framework. English teachers have to show results in terms of students' performance on school and state tests, thus students' and teachers' process of getting there becomes secondary. With disabled students, the path is harder and longer, but the efforts of teachers to include these students in foreign language practices are not being valued. (Howes, et al. 2005, p. 45) argue that "judging school success on the basis of academic results and pupil achievement alone may run counter to notions of inclusion and can discourage teaching practices that allow for student diversity."

Materials, including concrete materials, are appropriate to the needs, ages, interests, and aptitudes of the students: For this purpose, Index is a set of materials designed to support schools in the process of moving towards inclusive education. Its goal is to build "collaborative school communities that encourage high levels of achievement in all students" (Boot, 2000, p. 67). However, only a few educational institutions have information about or access to these resources.

Moreover, there is a clear disadvantage of public institutions in terms of supplies. Teachers barely cope with their access to limited textbooks and technologies that have to be used for all kinds of learners, regardless their particular characteristics. In the case of private institutions, many have acquired resources appropriate for some kinds of disabilities with parental and community support, but sometimes the absence of knowledge leads schools to make ineffective choices on the nature of materials to be implemented.

Appropriate time is allowed for practice, reinforcement, and application of new knowledge and skills in practical situations: In the NPB, the MEN allots three hours of English instruction for high school students and one hour in primary settings. In this short time, students are expected to get to B1 in their English proficiency. This expectation is really distant from reality, where teachers have to cope with big groups coming from numerous different contexts as well as manage planning, assessment, and their organizational and administrative responsibilities. There is usually not an opportunity to devote enough time to disabled students who demand more attention.

Opportunities are in place throughout the curriculum to enable 
students to develop language and communication skills (e.g., listening, speaking, reading, and writing) along with personal and social skills: UNESCO (2009, p. 19) states that

accessible and flexible curricula, textbooks and learning materials can serve as the key to creating schools for all. Many curricula expect all pupils to learn the same things, at the same time, and by the same means and methods. But pupils are different and have different abilities and needs.

Although inclusive policies in the country have recognized and further demanded the recognition of diversity, schools often are bound to curricular underpinnings that homogenize education and segregate diversity in educational practices. Teachers often do not find possibilities to adjust individual needs to curricular choices, and yet the responsibility lies only on them. (Calvo, Ortiz, and Sepulveda 2007, p. 33) argues that "responsibility for the inclusion in the curriculum is not of teachers or educational institutions; it is a problem of culture, politics and pedagogical practice."

Homework is designed to consolidate and extend, to promote independent learning, to monitor individual students' and class progress, and to evaluate the effectiveness of the teaching and learning: Homework is a powerful tool to reinforce knowledge and skills learned in the classroom. It also helps teachers to realize the pertinence of their pedagogical decisions and helps measure their students' learning progress. Foreign language learning needs to be supported by additional practice during which students have constant contact with the target language and parents are involved in the development of language awareness of their children. In the case of disabled students, they constantly need their relatives' support and feedback to perform homework exercises and practice their skills. However, there is still a great parental absence in sustaining the work of their children, either because they lack time and commitment or due to the poor knowledge they have in the foreign language.

MEN is aware of the challenges they still have to face in terms of inclusive education, so it invited schools to document experiences and best practices for educational inclusion. A group of specialists visited the settings with the greatest impact and awarded a prize for the best one (MEN, 2005). They aimed to extract relevant educational models for educational inclusion proposed in local settings and, by doing so, improve from real-time practice what has not been achieved from theory. However, there were no experiences documented in the arena of foreign language teaching.

To sum up, inclusion demands not only a shift in educational setting conditions but also a whole revolution in people's attitudes and values. Inclusive approaches must involve a 
rise in tolerance and understanding from governmental, non-governmental and societal actors. Discriminatory practices cannot be stopped solely with the physical integration of diverse needs into the classrooms; rather, the participation of students with special needs and vulnerabilities in making sociocultural and educational choices is called for, whereby their rights as human beings and learners are respected.

\section{Conclusions}

Inclusion is not a short and easy process; it entails the reshaping of behaviors and perspectives to reflect an appreciation of differences as a way to stop discrimination in different fields, including education. Policy makers and institutions have to start including guidelines and practices that can be applied to change the lens through which we see diversity.

Theory and practiceneed to beclosely linked, and there must be an alignment between the official documents that national and international entities create. The National Bilingual Program and various legislative acts mandating inclusion have emerged to integrate disabled and vulnerable populations, and if said inclusion is a mandatory practice for all educational institutions, foreign language programs must then refer to the guidelines and practices in the documents set by the Ministry of
National Education (MEN) to address the conditions in bilingual education.

The government and the institutions themselves must ensure an appropriate environment to instruct different kinds of students by placing value on their individual characteristics and providing an authentically inclusive experience in which the students are present throughout the pedagogical process, allowing them to participate, develop skills and apply knowledge meaningfully without restricting their potentialities.

The official documents that regulate bilingualism in Colombia need to include in their policies the language of inclusion which speaks to all members of society, encouraging them to accept differences and become involved in mutual learning communities, where all the students are welcome despite their physical or mental conditions.

Appropriate mechanisms and practices for curriculum creation are necessary to develop inclusive education, whereby there is solid collaboration between educators, policy makers, parents, school authorities, special education schools, and communities within and outside school settings.

Finally, sharing experiences would help English teachers to obtain ideas from colleagues' practices that they perhaps can apply to their own contexts. Teachers could come up with approaches and mechanisms that can be applied to address inclusion in foreign language teaching, despite the lack 
of suitable conditions and resources faced by many educational institutions nowadays.

\section{References}

Ainscow, M. (1999). Understanding the Development of Inclusive Schools. London: Falmer.

Booth, T. et al. (2000). The Index of Inclusion: developing learning and participation in schools. London: CSIE.

Calvo, G., Ortiz, A. \& Sepúlveda, E. (2007). La dificultad para concretar las normas en inclusión educativa. Ponencia presentada en el Taller Internacional sobre Inclusión Educativa América Latina - Regiones Cono Sur y Andina, Buenos Aires.

Cardona, M. (2006). Diversidad y Educación Inclusiva. Enfoques Metodológicos y

Estrategias para una Enseñanza Colaborativa. Madrid: Pearson Educación S.A.

Congreso de Colombia. (2006). Ley 1098 Código de Infancia y Adolescencia. Obtenido el 17 de marzo de 2010, desde http://www.presidencia.gov. co/prensa_new/leyes/2006/ Santiago Alberto Morales Mesa rev. eleuthera. Vol. 6, enero - junio 2012, págs. 127-147 147 noviembre/ley1098081106.pdf

Congreso de la República de Colombia. Ley 115, Por la cual se expide la ley general de educación. [Internet]. 1994 [citado 17 de noviembre de 2013]. Recuperado a partir de: http://www.mineducacion. gov.co/1621/articles-85906_archivo_ pdf.pdf
DENI (2006). The future role of the special school. Belfast: Author. Departamento Administrativo Nacional de Estadística. Dirección de censos y demografía. 2005.

Department of Science, Education and Training (2007, Sept). Improve the learning outcomes of students with disabilities in the early, middle and post compulsory years of schooling. Canberra: Commonwealth Government. Retrieved from: http://www.dest. gov.au/sectors/school_education/ publications_resources /profiles/ learning_ou tcomes_students_ disabilities .htm\#abstract

Eisenman, L. T., Pleet, A. M., Wandry, D., \& Mcginley, V.(2011). Voices of special education teachers in an inclusive high school: Redefining responsibilities. Remedial and Special Education 32, 91-104.

Howes, A., Booth, T., Dyson, A., and Frankham, J. (2005). Teacher learning and the development of inclusive practices and policies: Framing and context. Research Papers in Education 20 (2), 131-146.

Hurtado-Lozano LD, \& Agudelo-Martínez A. Inclusión educativa de las personas con discapacidad en Colombia. Revista ces mov. salud 2014; 2 (1):45-55

Londoño, A. (2012) Teaching and learning beyond academic-reality: An experience on teaching English to cognitively impaired learners. Universidad Tecnológica de Pereira, facultad de bellas artes y humanidades licenciatura en lengua inglesa, Pereira. 
Oliver, M. (1990). The Politics of Disablement. Basingstoke: Macmillan.

Putnam, J. (1998). Cooperative learning and strategies for inclusion. Baltimore: Paul Brookes.

Reynolds, M.C. \& Ainscow, M. (1994) Education of children and youth with special needs: an international perspective. In Husen, T. and Postlethwaite, T.N. (Eds.) The International Encyclopedia of Education, 2nd Edition Oxford: Pergamon.

UNESCO (1994) The Salamanca Statement and Framework for Action on Special Needs

Education. World Conference on Special Needs Education, Access and Quality. Retrieved from www.unesco.org/education/ educpro/sne/salamanc/index.htm.

UNESCO (2009). Policy guidelines on inclusion in education. Retrieved from :http:/ / www.inclusive-educationin action.org/iea/dokumente/ upload/72074_177849e.pdf.

Usma, W. (2009). Education and language policy in Colombia: Exploring processes of inclusion, exclusion, and stratification in times of global reform. Profile: Issues in Teachers' Professional Development, 11 (1), 123-141. 